\title{
Adsorption Kinetics and Dilatational Rheological Studies for the Soluble and Anchored Forms of Alkaline Phosphatase at the Air/Water Interface
}

\author{
Luciano Caseli, Douglas C. Masui, Rosa Prazeres M. Furriel, Francisco Assis Leone \\ and Maria Elisabete D. Zaniquelli*
}

\author{
Departamento de Química, Faculdade de Filosofia Ciências e Letras de Ribeirão Preto, \\ Universidade de São Paulo, 14040-901 Ribeirão Preto-SP, Brazil
}

\begin{abstract}
Este trabalho apresenta aspectos de equilíbrio e dinâmicos da adsorção na interface ar/líquido de duas formas de fosfatase alcalina de placa óssea de ratos: DSAP, solubilizada com tensoativo nãoiônico $\left(\mathrm{C}_{12} \mathrm{E}_{9}\right)$, contendo uma âncora de glicosilfosfatidilinositol (GPI), e PLSAP, com a porção hidrofóbica da âncora clivada por fosfolipase-C. A tensão superficial dinâmica, $\gamma_{\text {dyn }}$, e o módulo de elasticidade superficial dilatacional, $\varepsilon$, foram determinados para soluções de PLSAP, DSAP e $\mathrm{C}_{12} \mathrm{E}_{9}$ pelo método de oscilação harmônica e análise do formato da gota eixo-simétrica. Cinéticas de adsorção revelaram que DSAP adsorve trinta vezes mais rapidamente que PLSAP, apresentando um mínimo, e, para PLSAP, a tensão superficial cai continuamente. Para o sistema DSAP/C ${ }_{12} \mathrm{E}_{9}, \varepsilon$ atinge um máximo na concentração crítica de agregação (CAC), mas para PLSAP, $\varepsilon$ diminui continuamente com a concentração. Soluções de $\mathrm{C}_{12} \mathrm{E}_{9}$ apresentam $\varepsilon$ mais elevados, decrescentes com a concentração. Um modelo, baseado na influência da âncora GPI, é proposto para explicar os resultados obtidos.
\end{abstract}

This work presents equilibrium and dynamic aspects for the adsorption at the air/liquid interface of two rat osseous plate alkaline phosphatase forms: DSAP, solubilized by a surfactant, $\mathrm{C}_{12} \mathrm{E}_{9}$, and containing a glycosylphosphatidylinositol (GPI) anchor; and PLSAP, resulting from phospholipase-C cleavage of the hydrophobic portion of the GPI anchor. Dynamic surface tension, $\gamma_{\text {dyn }}$, and surface elasticity modulus, $\varepsilon$, were determined for PLSAP, DSAP and pure $\mathrm{C}_{12} \mathrm{E}_{9}$ solutions using harmonic oscillation and axisymmetric drop shape analysis Adsorption kinetics studies revealed that DSAP adsorbs thirty times faster than PLSAP, presenting a minimum in the curve. For DSAP/ $\mathrm{C}_{12} \mathrm{E}_{9}$ mixed system, $\varepsilon$ increases with concentration and a maximum appears at the critical aggregation concentration (CAC). For PLSAP, a continuous decreasing with concentration for $\gamma_{\mathrm{dyn}}$ and $\varepsilon$ was observed. For pure $\mathrm{C}_{12} \mathrm{E}_{9}$ solution the elasticity modulus increases with concentration and $\varepsilon$ values are higher when compared to the mixed system. A model based on the influence of the GPI anchor is proposed.

Keywords: dynamic surface tension, adsorption kinetics, dilatational surface elasticity, alkaline phosphatase, axisymmetric drop shape analysis

\section{Introduction}

Surface elasticity is associated with the ability of a system to establish a new surface tension value due to a timely area variation. Considering that it is a nonequilibrium phenomenon, changes in surface tension occur either as a consequence of a sudden compression/ expansion of the interface, or due to a local concentration variation. Since elasticity values are associated with diffusion processes, adsorption/desorption, as well as the rearrangement of molecules at the interface, they depend on the time scale (or frequency) in which the perturbation

* e-mail: medzaniquelli@ffclrp.usp.br is applied. In addition, these processes are influenced by molecular weight, shape and molecular interactions of the species present at the interface.

Surface elasticity is directly related to the stability of emulsions and foam films, ${ }^{1,2}$ as well as certain bio-processes occurring in cell membranes, such as, oxygen exchange in the membranes of the lung alveolae. ${ }^{3,4}$ Moreover, some enzymatic processes occurring at the membrane level depend on the lipid/protein film surface packing and elasticity.

It has been recently demonstrated in our laboratory that there is a correlation between the equilibrium surface compressibility of a planar mixed lipid/enzyme monolayer and the catalytic activity of a glicosylphosphatidil-inositol (GPI) anchored enzyme, ${ }^{5}$ with the enzyme reaction 
occurring more efficiently for a characteristic lipid/enzyme surface packing. Such packing is associated with a surface compressibility that most likely optimizes the access of the substrate, which is dissolved in the bulk subphase, to the enzyme active site.

We have studied the p-nitrophenylphosphate hydrolysis by a rat osseous plate alkaline phosphatase. This membrane enzyme (Figure 1) can be solubilized either by non-ionic surfactants ${ }^{6}$ or by a glycosylphosphatidylinositol-specific phospholipase-C. ${ }^{7}$ The detergent solubilized form (DSAP) is a dimer of two apparently identical subunits of Mr $65 \mathrm{kDa}$ each, and includes the intact GPI anchor. ${ }^{7}$ In spite of the absence of the diacylglycerol moiety, ${ }^{8}$ the phosphatidylinositolspecific phospholipase C-solubilized alkaline phosphatase (PLSAP) shows quite close structural and catalytic properties in homogeneous medium to those of DSAP. ${ }^{9}$ However, its heterogeneous catalysis differs significantly from that of DSAP. ${ }^{10}$ These two enzyme forms provide a very interesting possibility for comparative studies at air/water interfaces, in order to verify the effect of the hydrophobic anchor on the surface properties.

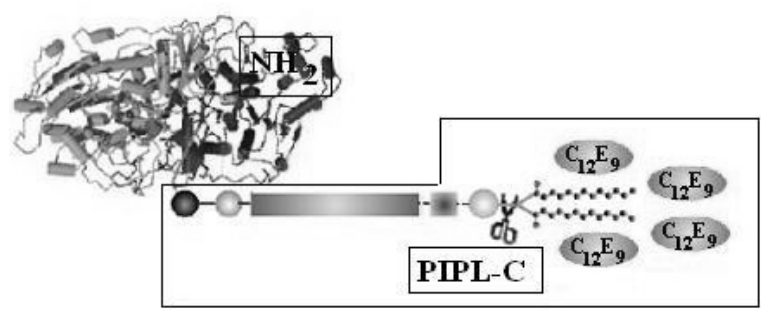

Figure 1. Scheme for alkaline phosphatase structure. The region inside the rectangle represents the GPI anchor. carboxy-terminal group of the polypeptide moiety, $\mathrm{P}$ phosphate group, $\square$ inositol, glycan chain. The scissors indicates the linkage cleaved by phospholipase $\mathrm{C}$ (PIPL-C) to release PLSAP from the membrane. Polidocanol $\left(\mathrm{C}_{12} \mathrm{E}_{9}\right)$ acts mainly at the hydrophobic tail in order to solubilize the anchor containing form of the enzyme (DSAP).

In this work we show a comparative study of the equilibrium and dynamic properties at air/liquid interfaces of DSAP and PLSAP, employing the harmonic drop oscillation method associated to the axisymmetric drop shape analysis. To our knowledge, this is the first work reporting the effect of the GPI-anchor on the GPI-protein film surface elasticity.

\section{Background}

Some years ago, the devices employed to measure film elasticity used to be completely developed at university's or company's laboratories. Contributions were made by several research groups, ${ }^{11-17}$ using different experimental set-ups. Among the developed techniques, the harmonic drop oscillation associated with axisymmetric drop shape analysis (ADSA) is currently commercially available. ${ }^{18-20}$

The surface dilatational elasticity, also called surface elasticity or surface elasticity modulus, $\varepsilon$, is defined as:

$\varepsilon=\mathrm{d} \gamma / \mathrm{d} \ln \mathrm{A}$

where $d \gamma$ accounts for the infinitesimal surface tension gradients upon a relative area (A) variation. The equilibrium value is the Young modulus and is identified as the Gibbs elasticity, also called compressibility modulus $\left(\mathrm{C}_{\mathrm{s}}^{-1}\right)$ for Langmuir monolayers.

Under dynamic conditions, there are films ranging from perfectly viscous to perfectly elastic, with the latter occurring only when no relaxation process takes place in the timescale of the experiment. This fact means that there is no phase difference (described by a phase angle, $\theta$ ) between the perturbation (deformation) and the response of the system (change in surface tension). On the other hand, phase differences are characteristic of the interface viscoelastic behavior. This feature is accounted by introducing a complex modulus:

$\varepsilon=|\varepsilon| \cos \theta+\mathrm{i}|\varepsilon| \sin \theta$

The imaginary part of this quantity accounts for the energydissipation process and is related to surface dilatational viscosity $\left(\eta_{\sigma}\right)$ :

$\eta_{\sigma}=(|\varepsilon| \sin \theta) / \omega$

in which, the angular frequency, $\omega=2 \pi f$, is established when a sinusoidal disturbance with a frequency $f$ is imposed to the interface.

Both the change in area and the variations in surface tension are calculated by fitting the drop shape to the Young-Laplace equation:

$\Delta \mathrm{P}=\left(\rho_{\mathrm{d}}-\rho_{1}\right) \mathrm{gh}=\left(\gamma / \mathrm{R}_{1}\right)+\left(\gamma / \mathrm{R}_{2}\right)$

where $\Delta \mathrm{P}$ is the difference of pressure across the interface, $\rho_{d}-\rho_{1}$ are the densities of the denser and the lighter phases, respectively, $\mathrm{g}$ is the gravity acceleration, $\mathrm{h}$ is the height of the liquid column at the drop and $R_{1}, R_{2}$ the two main drop curvature radius.

\section{Experimental}

\section{Materials}

All solutions were prepared using dust free Milli-Q ${ }^{\circledR}$ 
water (surface tension of $72.8 \mathrm{mN} \mathrm{m}^{-1}$ and resistivity of 18.2 $\mathrm{M} \Omega \mathrm{cm}$ ). Tris buffer and polyoxyethylene-9-lauryl ether (polidocanol, $\mathrm{C}_{12} \mathrm{E}_{9}$ ) were purchased from Sigma Chemical Co; purified phosphatidylinositol-specific phospholipase $\mathrm{C}$ (PIPLC) from Bacillus thuringiensis was purchased from Oxford Glyco Sciences Inc. (England). All other reagents were of the highest purity commercially available.

\section{Preparation of detergent-solubilized alkaline phosphatase}

DSAP was prepared from alkaline phosphatase-rich rat osseous plate membranes. ${ }^{21}$ Samples of membrane-bound alkaline phosphatase $\left(0.2 \mathrm{mg} \mathrm{mL}^{-1}\right)$ were solubilized with $1 \% \mathrm{C}_{12} \mathrm{E}_{9}$, (final concentration) for $2 \mathrm{~h}$, at $25^{\circ} \mathrm{C}$, under constant stirring. After centrifugation at $30,000 \mathrm{~g}$ for $2 \mathrm{~h}$, DSAP was concentrated on an YM-5 Amicon filter and dialyzed overnight against $5 \mathrm{mmol} \mathrm{L}^{-1}$ Tris. $\mathrm{HCl}$ buffer, $\mathrm{pH}$ 7.5 , containing $2 \mathrm{mmol} \mathrm{L}^{-1} \mathrm{MgCl}_{2}, 150 \mathrm{mmol} \mathrm{L}^{-1} \mathrm{NaCl}$ and $0.01 \% \mathrm{C}_{12} \mathrm{E}_{9}$. Finally, DSAP was purified on a Sephacryl S300 column $(130 \times 1.7 \mathrm{~cm})$ equilibrated and eluted in the same buffer. The solubilized enzyme was maintained in crushed ice for a period no longer than a month, without appreciable loss of activity. It should be emphasized that solubilization does not remove the GPI anchor.

\section{Preparation of enzymatically-solubilized alkaline phosphatase}

The phospholipase C-released rat osseous plate alkaline phosphatase (PLSAP) was solubilized from alkaline phosphatase-rich rat osseous plate membranes using PIPLC from B. thuringiensis. ${ }^{7}$ Briefly, aliquots (2 $\mathrm{mg} \mathrm{mL} \mathrm{L}^{-1}$ ) of membrane-bound alkaline phosphatase were incubated with $0.1 \mathrm{U}$ PIPLC for $1 \mathrm{~h}$, at $37^{\circ} \mathrm{C}$. After a centrifugation at $100,000 \times$ g for $1 \mathrm{~h}$, at $4^{\circ} \mathrm{C}$, the supernatant was carefully removed and PLSAP was purified on a Phenyl-Sepharose CL-4B column $(1 \times 10 \mathrm{~cm})$. The active fractions were pooled and dialyzed overnight, at $4{ }^{\circ} \mathrm{C}$, against $5 \mathrm{mmol} \mathrm{L}^{-1}$ Tris. $\mathrm{HCl}$ buffer, $\mathrm{pH} 7.5$, containing 2 $\mathrm{mmol} \mathrm{L}-1 \mathrm{MgCl}_{2}$. Samples of $0.1 \mathrm{~mL}$ were rapidly frozen in liquid nitrogen and stored at $-20^{\circ} \mathrm{C}$ for a period no longer than a month without appreciable loss of activity.

\section{Surface tension and surface elasticity measurements}

Surface tension and surface elasticity were determined using an optical contact angle meter, OCA-20, with oscillating drop accessory ODG-20 from Dataphysics Instruments $\mathrm{GmbH}$, Germany. A drop of liquid, formed from a syringe into a thermostated optical glass cuvette containing water in the bottom to avoid drop evaporation, is imaged using a CCD camera. A specific software that uses a suitable position for a reference line in the image field was accessed to trigger the recording of the images even before the complete drop formation. The zero time is defined after playing the movie by selecting the suitable images and surface tension was determined by firstly digitizing and analyzing the profile of the droplet. Then, the Laplace equation was fitted to the shape of the drops.

For the elasticity measurements, the images were recorded with a video camera with a minimum of 200 frames per second. At the end of the experiment, the software retrieves the images and calculates the change in area and respective changes in surface tension for each cycle. Using a Fourier transform analysis, the elasticity $(\varepsilon)$ and phase angle $(\theta)$ were determined.

The drop oscillation is initiated after the surface tension reached a constant value. A piezo actuator device, connected to a function generator and located above the needle produces a sinusoidal movement of the drop in a specified frequency at the control table.

For the experiments described in this work, surface tension and elasticity measurements of aqueous solutions of $\mathrm{C}_{12} \mathrm{E}_{9}$, DSAP and PLSAP were carried out at $23 \pm 0.5^{\circ} \mathrm{C}$; Tris. $\mathrm{HCl}$ buffer, $\mathrm{pH} 7.5$, was used as the heavier phase and air as the lighter phase. Frequencies between 0.1 and $1 \mathrm{~Hz}$ were tested, and the amplitude of $0.1 \mathrm{~mm}$ (relative area variation of 5.5\%) and the frequency of $0.841 \mathrm{~Hz}$ were arbitrarily chosen in order to compare the different systems.

\section{Surface pressure-area isotherms}

To obtain the equilibrium surface compressibilities $\left(\mathrm{C}_{\mathrm{s}}\right.$ $\left.=-1 / \mathrm{A}(\partial \mathrm{A} / \partial \pi)_{\mathrm{T}}\right)$ of DSAP monolayers at planar air/water interfaces, surface pressure $(\pi)$-area (A) compression isotherms were carried out. The buffer Tris- $\mathrm{HCl} \mathrm{pH} 7.5$ was used as subphase in a homemade trough with a volume of $40 \mathrm{~mL}$ and a total area of $4892 \mathrm{~mm}^{2}$. Aliquots of $c a .58 \mu \mathrm{L}$ of a $6.9 \mu \mathrm{g} \mathrm{mL}^{-1}$ DSAP solution were spread on the top of the surface, and after 15 minutes a stable surface pressure was obtained. The surface pressure-area curves were obtained by moving the barrier at $6.73 \mathrm{~mm}^{2} \mathrm{~s}^{-1}$. The temperature was maintained constant at $23 \pm 0.5^{\circ} \mathrm{C}$.

\section{Results and Discussion}

\section{Dynamic surface tension}

PLSAP can be compared to other soluble globular proteins such as human or bovine serum albumin (HSA, BSA), ovoalbumin (OVA) or lactoglobulines, with a 
approximately ellipsoidal native structure. In order to investigate the mechanism of PLSAP adsorption, dynamic surface tension curves (Figure 2) were obtained using the pendant drop technique and the drop shape analysis. The adsorption kinetics at short-times is better visualized in logarithmic scale (inset of Figure 2). For a $50 \mu \mathrm{g} \mathrm{L}^{-1}$ $\left(3.85 \times 10^{-10} \mathrm{~mol} \mathrm{~L}^{-1}\right)$ concentration, the surface tension becomes stable after about $6 \mathrm{~h}$. The decrease in surface tension becomes faster for more concentrated enzyme solutions, and for a concentration of $250 \mu \mathrm{g} \mathrm{\textrm {L } ^ { - 1 }}(4.28 \mathrm{x}$ $10^{-7} \mathrm{~mol} \mathrm{~L}^{-1}$ ), the stabilization is reached in less than $3 \mathrm{~h}$. For higher concentrations, both the equilibrium surface tension and the equilibrium time no longer change. The induction time (time required to measure a decrease of about $0.5 \mathrm{mN} \mathrm{m}^{-1}$ in surface tension - also known as lag time $)^{22}$ is about $800 \mathrm{~s}$. This lag time is comparable with that calculated $(\log t(s)=2-3)$ for a model protein solution at $10^{-7} \mathrm{~mol} \mathrm{~L}^{-1}$, using a kinetic model. ${ }^{23}$ However, they are higher than those obtained for other globular enzymes as those reported ${ }^{24}$ for lysozyme and $\beta$-casein, both with low molecular masses ( $14.3 \mathrm{kDa}$ and $24 \mathrm{kDa}$, respectively) and at higher concentrations (5-8.5 $\left.\mathrm{mg} \mathrm{L}^{-1}\right)$. For these proteins, induction times of few seconds were observed. It must be stressed that PLSAP has a very higher molecular mass (130 $\mathrm{kDa}$ ), when compared with those proteins.

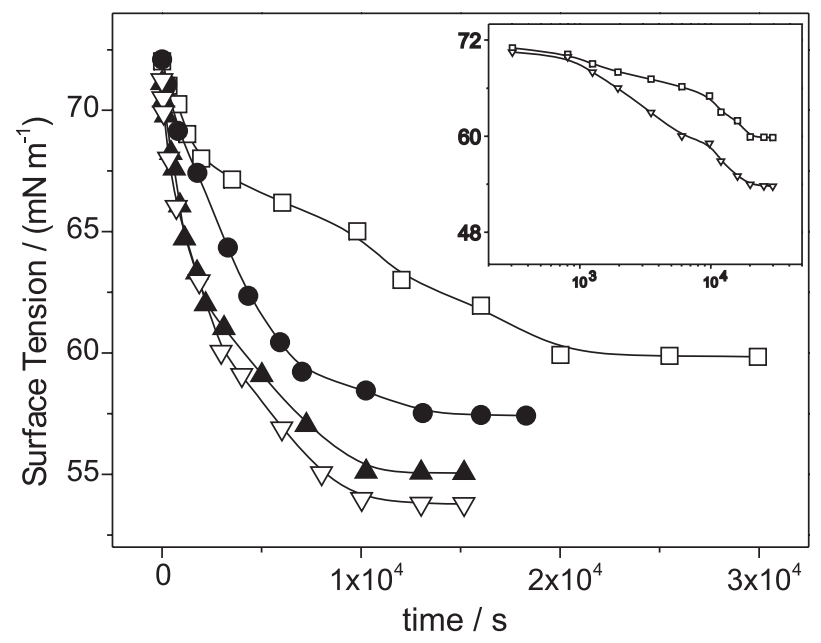

Figure 2. PLSAP adsorption kinetics at air/water interface. Concentrations $\left(\mu \mathrm{g} \mathrm{L}^{-1}\right): \square 50,-100, \boldsymbol{\Delta} 200, \nabla 250$. The inset shows the adsorption in logarithmic scale for high $\left(250 \mu \mathrm{g} \mathrm{L}^{-1}\right)$, and low $\left(50 \mu \mathrm{g} \mathrm{L}^{-1}\right)$ PLSAP concentrations.

Figure $3 \mathrm{~A}$ brings results for DSAP concentrations below and above $\mathrm{CAC}$ of the system $\left(3.6 \times 10^{-6} \mathrm{~mol} \mathrm{~L}^{-1}\right.$ of $\mathrm{C}_{12} \mathrm{E}_{9}$ for $180 \mu \mathrm{g} \mathrm{L}^{-1}$ of the enzyme). ${ }^{25} \mathrm{It}$ is observed that for an enzyme concentration of $5 \mu \mathrm{g} \mathrm{L}^{-1},\left(\mathrm{C}_{12} \mathrm{E}_{9} 10^{-7} \mathrm{~mol} \mathrm{~L}^{-1}\right)$, the system takes 15 minutes to become stable. Above the CAC, a constant surface tension of about $53 \mathrm{mN} \mathrm{m}^{-1}$ is reached in less than $5 \mathrm{~min}$. For this system, an induction time is not
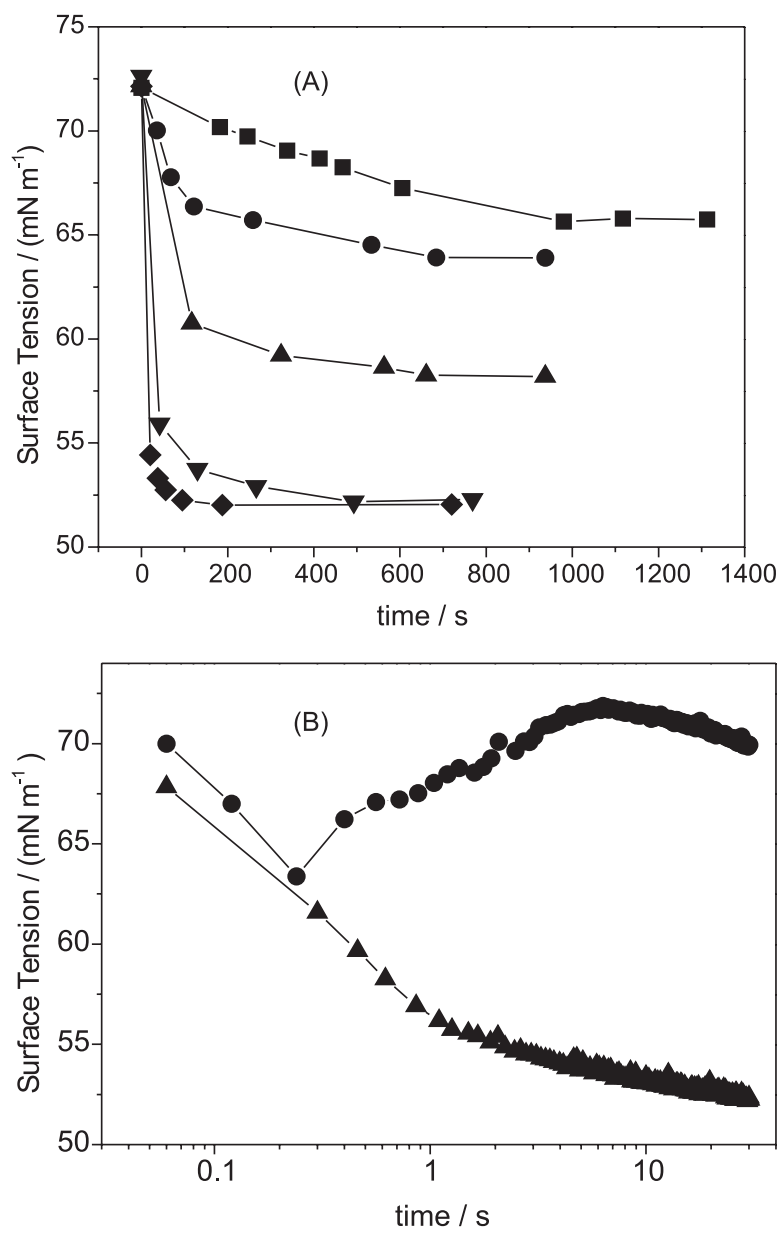

Figure 3. DSAP adsorption kinetics at air/water interface. (A) Long adsorption times. Enzyme/surfactant ratio is $0.04 \%$ (in mol). Enzyme concentrations and $-\log \left(\left[\mathrm{C}_{12} \mathrm{E}_{9}\right] / \mathrm{mol} \mathrm{L}^{-1}\right)$ are, respectively: $5 \mu \mathrm{g} \mathrm{L}^{-1}$ and 7, $50 \mu \mathrm{g} \mathrm{L}^{-1}$ and $6, \boldsymbol{\Delta} 125 \mu \mathrm{g} \mathrm{L}^{-1}$ and $5.4, \nabla 400 \mu \mathrm{g} \mathrm{L}^{-1}$ and 5,

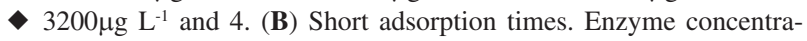
tions: $5 \mu \mathrm{g} \mathrm{L}^{-1}, \boldsymbol{\Delta} 3200 \mu \mathrm{g} \mathrm{L} \mathrm{L}^{-1}$

detected in the time scale of the experiment for the entire studied concentration range.

The faster adsorption kinetics of DSAP compared to PLSAP is probably due to the presence of the hydrophobic moiety of the GPI anchor in the former and absent in the latter. The anchor provides an amphiphilic character to the enzyme and is responsible for the much lower concentration necessary to decrease the surface tension (at concentrations of $5 \mu \mathrm{g} \mathrm{L^{-1 }}$, no variation in surface tension is detected for PLSAP after 12 hours of experiment). Moreover, the intact GPI anchor is also responsible for the DSAP ability to produce Langmuir monolayers ${ }^{26}$ (above the CAC, the enzyme is solubilized in the buffer solution).

On the other hand, considering the absence of the hydrophobic anchor in PLSAP and, therefore, its high hydrophilic character, it is very likely that, during its air/ water interface adsorption, a certain denaturation takes 
place at the interface due to the exposition of the hydrophobic groups..$^{27-31}$

Figure 3B shows the kinetics for DSAP adsorption in short times (less than 30s). For the highest DSAP concentration $\left(3200 \mu \mathrm{g} \mathrm{L}^{-1}\right)$, the surface tension falls down continuously, reaching $52 \mathrm{mN} \mathrm{m}^{-1}$ in $10 \mathrm{sec}$. For the lowest DSAP concentration studied $\left(5 \mu \mathrm{g} \mathrm{L}^{-1}\right)$, the surface tension initially falls down to $63 \mathrm{mN} \mathrm{m}^{-1}$, increases smoothly to 72 $\mathrm{mN} \mathrm{m}^{-1}$ (roughly zero surface pressure) and, after that, decreases slowly, a constant value being reached after roughly $15 \mathrm{~min}$ (Figure 3A). This effect is reproducible and it is observed for DSAP concentrations as high as $125 \mu \mathrm{g}$ $\mathrm{L}^{-1}$, but not observed for any concentration of PLSAP (Figure 2). As this process occurs only at low enzyme concentrations, there is a high area per molecule available, so it is likely that protein molecules undergo more rearrangements than it would be possible with the dense packing at the interface associated with a high enzyme concentration. Thus, this behavior may be ascribed to a three-step adsorption mechanism: (i) lateral diffusion of the enzyme at the incipient area available just before the drop formation or present in the sub-layer region, and rapid adsorption provided by the hydrophobic moiety of the GPI anchor; (ii) re-orientation of the GPI molecules at the air/water interface to a perpendicular plane relative to the interface, probably by the rearrangement of the macromolecules at the interface and (iii) adsorption of the remaining molecules present in the bulk solution.

The influence of $\mathrm{C}_{12} \mathrm{E}_{9}$ on the DSAP mixed system can also be verified by the dynamic surface tension for the pure nonionic surfactant, as depicted in Figures 4A and B. The concentration range corresponds to the surfactant concentrations in the mixed system. In all cases, the equilibrium surface tension is roughly 10 units lower for the pure surfactant when compared to the mixed system. The time to reach a constant surface tension is longer than that required for the mixed system, in which the insoluble-in-water enzyme is present. For a concentration of about $1.0 \times 10^{-7} \mathrm{~mol} \mathrm{~L}^{-1}$, approximately two and a half hours are necessary for the surface tension to reach a stable value, similarly as reported by Ravera et al. ${ }^{32}$ for $\mathrm{C}_{10} \mathrm{E}_{5}$. However, when $\mathrm{C}_{12} \mathrm{E}_{9}$ concentration is increased to or higher than $3.26 \times 10^{-5} \mathrm{~mol} \mathrm{~L}^{-1}$, only a few minutes (less than 20min) are necessary to reach the equilibrium surface tension. Figure 4B shows the kinetics of adsorption of $\mathrm{C}_{12} \mathrm{E}_{9}$ at short times. An induction time is observed for the lowest concentration. However, differently from the results obtained for DSAP, no minimum is seen in the curve for pure $\mathrm{C}_{12} \mathrm{E}_{9}$ in a concentration equivalent to that in the mixed system. This behavior suggests that the effect observed for the mixed system is, in fact, mainly due to the protein component of the mixture.
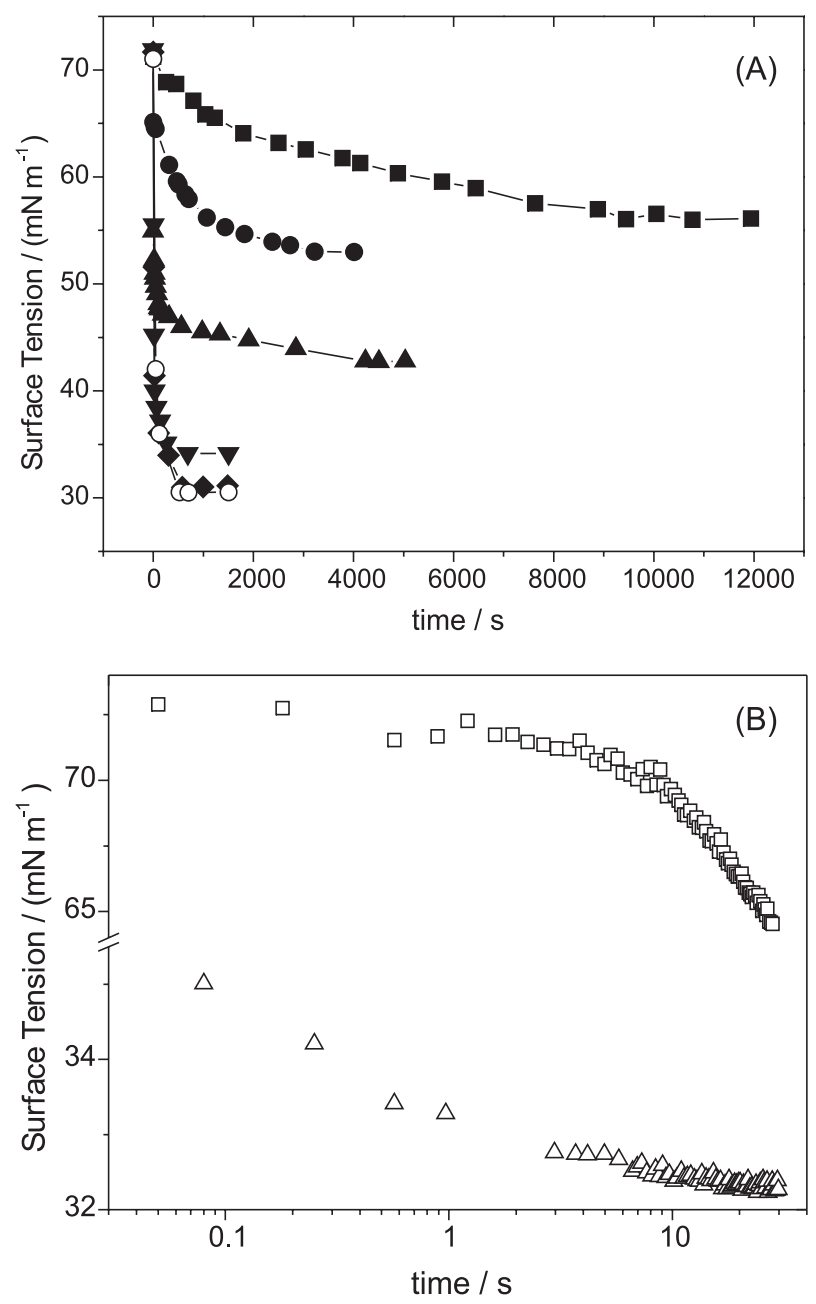

Figure 4. $\mathrm{C}_{12} \mathrm{E}_{9}$ adsorption kinetics at air/water interface. (A) Surfactant concentrations as $-\log \left(\left[\mathrm{C}_{12} \mathrm{E}_{9}\right] / \mathrm{mol} \mathrm{L}^{-1}\right)$ are: $\mathbf{\square}, \bullet 6, \boldsymbol{\Delta} 5, \boldsymbol{\nabla} 4.5$, $\checkmark 4$ and $\bigcirc$ 3.5. (B) Short times. Concentrations: $\square 10^{-7} \mathrm{~mol} \mathrm{~L}^{-1}$, $\triangle 3.15 \times 10^{-4} \mathrm{~mol} \mathrm{~L}^{-1}$

\section{Elasticity measurements}

Figure 5 shows an example of surface tension variation in response to the deformation of the interfacial area. From this example, the phase angle is practically zero, which means that the interface has a perfect elastic behavior. A deviation from zero corresponds to viscoelastic effects, ${ }^{13}$ which are in fact observed for some of the analyzed frequencies. However, in all cases, the elastic component is dominant.

As the elasticity modulus ( $\varepsilon$ ) depends on the frequency, this parameter was changed from 0.01 to $1.0 \mathrm{~Hz}$. This frequency range corresponds to relaxation times characteristic for different protein $\mathrm{s}^{33,34}$ and is associated to rearrangement processes. As the obtained results show the same tendency, the frequency of $0.841 \mathrm{~Hz}$ and relative area variation of $5.5 \%$ (corresponding to the mechanical amplitude of $0.1 \mathrm{~mm}$ of the piezo system) were arbitrarily chosen to compare the data for the two proteins and for the 


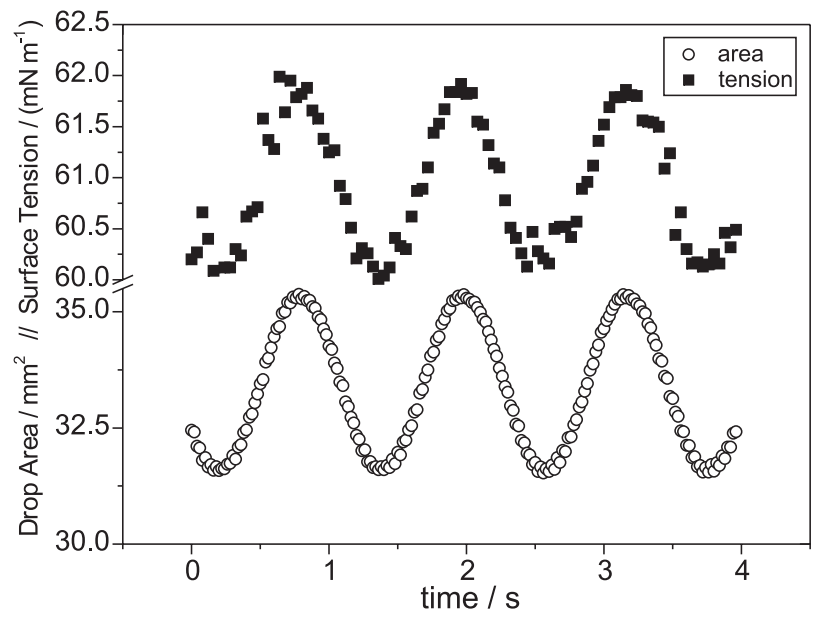

Figure 5. Example of crude data of surface area and surface tension sinusoidal oscillations used to determine the dilatational elasticity of a $50 \mu \mathrm{g} \mathrm{L}^{-1} \mathrm{DSAP}$ solution. The frequency applied is $0.841 \mathrm{~Hz}$ and the mechanical amplitude is $0.1 \mathrm{~mm}$, corresponding to a relative area variation of $5.5 \%$. Observe that there is no phase angle difference $\left(\theta=0^{\circ}\right)$

non-ionic surfactant. This amplitude is small enough to prevent the detachment of the drop from the syringe tip during the compression/expansion process and also does not impart problematic diffusion/convection effects.

The dependence of the dilatational elastic moduli $(\varepsilon)$ on the concentration for DSAP is shown in Figure 6. Elasticity for $\mathrm{C}_{12} \mathrm{E}_{9}$ is shown in the same plot for comparison. For $\mathrm{C}_{12} \mathrm{E}_{9}$ the elasticity decreases continuously with the concentration. In previous studies using other polyoxyethylene alkyl ether surfactants and similar frequencies ${ }^{35}$ a small decrease in the elasticity modulus has been observed. However, the concentration range used in that work $\left(5 \times 10^{-12}-10^{-10} \mathrm{~mol} \mathrm{~L}^{-1}\right)$ was lower than that used in this work $\left(10^{-7}-10^{-4} \mathrm{~mol} \mathrm{~L}^{-1}\right)$. In addition, for $\mathrm{C}_{12} \mathrm{E}_{4}$, Stuberauch and Miller ${ }^{36}$ reported a decrease of the elasticity modulus with increasing surfactant concentrations (in the range of $\left.10^{-5}-10^{-4} \mathrm{~mol} \mathrm{~L}^{-1}\right)$ at a frequency lower than $1.00 \mathrm{~Hz}$.

On the other hand, in the case of DSAP the elasticity reaches a maximum at the CAC. According to some authors, ${ }^{37}$ there is a competitive adsorption between the constituent species of mixed soluble protein/non-ionic surfactant systems. DSAP constitutes, however, a peculiar system due to the presence of the GPI anchor, and its solubility in water, as well as its adsorption, depends on the non-ionic surfactant concentration. From Figure 6, it may be observed that the CAC represents a limit to the elasticity. For higher concentrations, there is a reduction in $\varepsilon$, meaning that the solubilization of the GPI-anchored protein makes the air/water interface more resistant to a gradient of surface tension due to diffusive effects. Moreover, between $\mathrm{C}_{12} \mathrm{E}_{9}$ concentrations of $3.6 \times 10^{-6}$ and $7.1 \times 10^{-5} \mathrm{~mol} \mathrm{~L}^{-1}, \mathrm{CAC}$ and $\mathrm{CMC}$ respectively, the elasticity values for the DSAP/ $\mathrm{C}_{12} \mathrm{E}_{9}$ system and pure $\mathrm{C}_{12} \mathrm{E}_{9}$ are close.

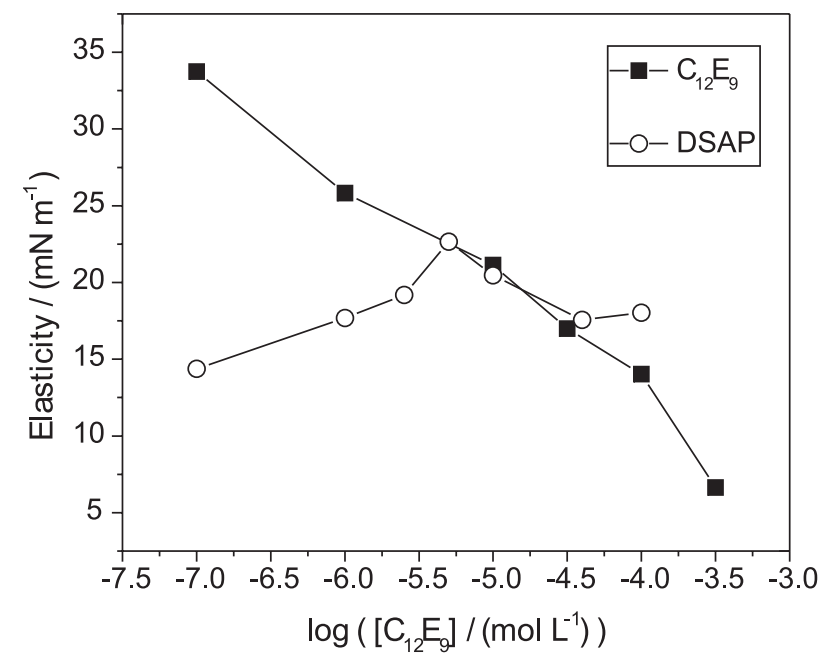

Figure 6. Effect of concentration on the elasticity. The maximum in the curve for DSAP corresponds to the CAC (critical aggregation concentration for the alkaline phosphatase- $\mathrm{C}_{12} \mathrm{E}_{9}$ mixed system).

In contrast, for concentrations higher than the CAC, the elasticity modulus for pure $\mathrm{C}_{12} \mathrm{E}_{9}$ continuously decreases, whereas the mixed system maintains a constant elasticity. This fact indicates that the interaction of the DSAP anchor with $\mathrm{C}_{12} \mathrm{E}_{9}$ can limit the diffusion of the non-ionic surfactant (or even of the enzyme) to the interface.

In order to compare the dynamic dilatational elasticity measured at the drop surface with the equilibrium compressional modulus at the planar interface, surface pressure-area $(\pi-\mathrm{A})$ compression isotherms were obtained (Figure 7). At selected pressures, the compressional moduli, taken as $-\mathrm{d} \pi / \mathrm{d} \ln \mathrm{A}$, are displayed on the graph. Table 1 compares the dynamic surface elasticity and the equilibrium surface compressional modulus. The values obtained at the same pressures do not differ more than $11 \%$ from each other, being the highest difference observed at $19.9 \mathrm{mN} \mathrm{m}^{-1}$, close to the collapse pressure $\left(20.2 \mathrm{mN} \mathrm{m}^{-1}\right)$. For surface pressures above $20 \mathrm{mN} \mathrm{m}^{-1}$, the values cannot be compared because the phenomena occurring in the two systems are different. For the equilibrium regime (Langmuir trough) the monolayer attained the "collapse", and due to the high volume of the subphase (around $40 \mathrm{~mL}$ ), the concentration of the enzyme $/ \mathrm{C}_{12} \mathrm{E}_{9}$ system is still below the CAC and, therefore, the enzyme cannot be solubilized. At the collapse,

Table 1. Dynamic dilatational surface elasticity ( $(\varepsilon)$ (drop) and equilibrium surface compressibility modulus $\left(\mathrm{C}_{\mathrm{s}}^{-1}\right)$ (trough), for DSAP monolayers at the specified surface pressure $(\pi)$

\begin{tabular}{ccc}
\hline$\pi\left(\mathrm{mN} \mathrm{m}^{-1}\right)$ & $\mathrm{C}_{\mathrm{s}}^{-1}\left(\mathrm{mN} \mathrm{m}^{-1}\right)$ & $\varepsilon\left(\mathrm{mN} \mathrm{m}^{-1}\right)$ \\
\hline 7.1 & 13.6 & 14.4 \\
8.8 & 17.2 & 17.7 \\
14.6 & 20.1 & 19.2 \\
19.9 & 25.1 & 22.7 \\
\hline
\end{tabular}




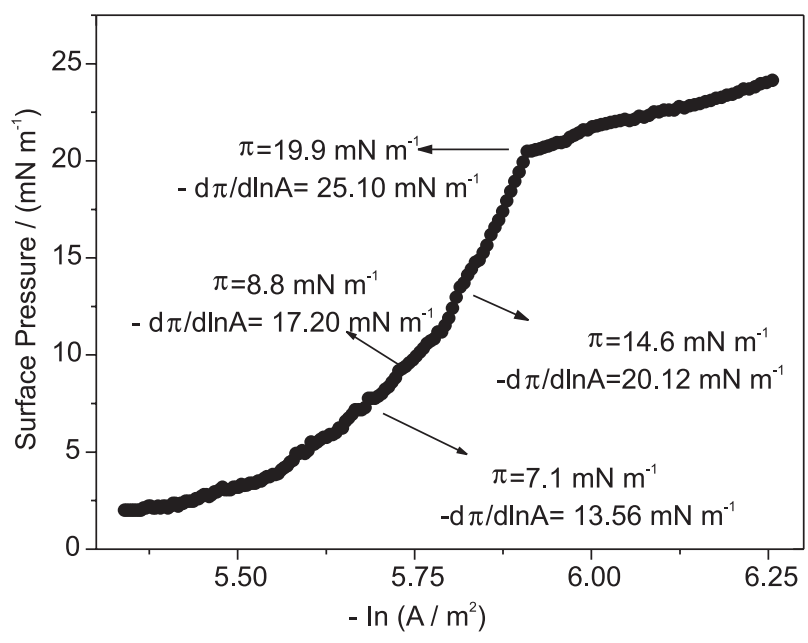

Figure 7. Surface pressure-area compression isotherm for DSAP Langmuir monolayer at planar air/water interface. Area corresponds to the total available surface of the trough. Compression velocity: $6.73 \mathrm{~mm}^{2} \mathrm{~s}^{-1}$.

there is a rearrangement at the air/water interface, with the possibility of multilayer formation. On the other hand, in the drop, the surface tension of $20 \mathrm{mN} \mathrm{m}^{-1}$ is attained with increasing concentrations of the enzyme/ $\mathrm{C}_{12} \mathrm{E}_{9}$ system in such a way that the CAC is attained, and molecules can be displaced to the bulk solution (subphase).

The elasticity for the globular soluble PLSAP (Figure 8) was also studied. It decreases continuously with concentration, showing a more pronounced decay at $10^{-2} \mu \mathrm{g} \mathrm{L} \mathrm{L}^{-1}$. The elasticity values (between 10 and $14.5 \mathrm{mN} \mathrm{m}^{-1}$ for the frequency studied) are lower when compared with those reported for other hydrophilic and globular proteins. The elasticity moduli for air/water interfaces for solutions of standard proteins with lower molecular weights, like BSA, HSA, $\beta$-casein and $\beta$-lactoglobulin, were measured by many authors, using various techniques. ${ }^{31,38-41}$ For instance, $\beta$-lactoglobulin $\left(\mathrm{M}_{\mathrm{r}} 18.4 \mathrm{kDa}\right)$ shows an average elasticity of $26.04 \mathrm{mN} \mathrm{m}^{-1}$ for a frequency of $0.0125 \mathrm{~Hz}$, at a concentration around $1 \times 10^{-7} \mathrm{~mol} \mathrm{~L}^{-1} \cdot{ }^{33}$ Nevertheless, Benjamins et al. ${ }^{38}$ have already pointed out that the interfacial pressure rather than the bulk concentration is the most relevant parameter to compare the moduli. Thus, the value of $17.3 \mathrm{mN} \mathrm{m}^{-1}$ obtained for BSA, measured at a surface pressure of $56.2 \mathrm{mN} \mathrm{m}^{-1}$, should be compared to the elasticity obtained for other globular proteins at the same surface pressure. Table 2 summarizes a comparison between our results and other elasticity values obtained from the literature. Compressibility for in-planar surface PLSAP monolayers was not obtained due to the high solubility of the enzyme, and the use of high ionic strength, which could prevent the its solubilization, was not employed due to the likely denaturation of the enzyme.

Furthermore, PLSAP exhibits lower values of $\varepsilon$, if compared to DSAP (see Figures 6 and 8). This fact can be

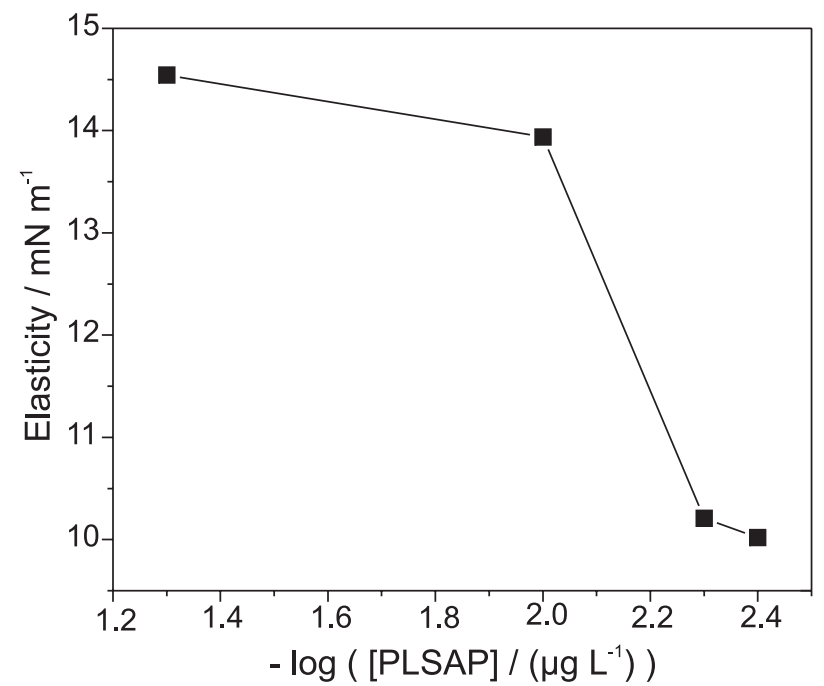

Figure 8. Effect of concentration on the elasticity of PLSAP films. The surface tension values studied are $60.5,58,55$ and $54 \mathrm{mN} \mathrm{m}^{-1}$ (from the least to the most concentrated solution).

attributed to the higher DSAP surface activity due to the GPI anchor. Since the surface dilatational elasticity indicates the ability of the interface to restore the original surfactant surface density providing a surface tension gradient, the GPI-anchored enzyme is able to resist to changes in area much more efficiently than the globular soluble enzyme without the anchor. Thus, the GPI-anchored enzyme DSAP can also be associated to a better ability to stabilize films. ${ }^{14}$ Moreover, the elasticity for both proteins must be associated to a reversible movement of the protein segments ${ }^{42}$ which could also be a relevant factor for enzymatic processes. However, as the DSAP form contains a hydrophobic anchor, it is strongly likely that its major elasticity effects are related to the capability of the anchor to be adsorbed on air/water interfaces. Since few enzyme molecules are present in the bulk solution, the Gibbs mechanism for surface pressure regeneration can be neglected, which provides the higher enzyme ability in resisting to an area gradient, followed by a surface tension gradient.

The dilatational effects for both enzyme forms may be also associated with different conformation and orientation changes at the air/water interface. Alkaline phosphatase has an ellipsoidal shape, ${ }^{43}$ and, according to a previous work, ${ }^{10}$ its orientation at the interface (major axis parallel or perpendicular to the interface) is strongly influenced by the presence or not of the hydrophobic anchor. Therefore, the higher or lower capability of the enzyme molecules to pack at the interface, as well as the protein solvation ${ }^{20,44-45}$ may lead to the different velocities of adjustments of the steady state. In this sense, to rebuild the surface structure with a high mechanical stability, the conformational and orientation changes must not be highly restricted. In our case, the presence of a phospholipid (hydrophobic anchor) 
Table 2. Comparison of elastic moduli for PLSAP and other globular proteins measured at similar surface pressures

\begin{tabular}{|c|c|c|c|c|c|}
\hline Protein(concentration) & Frequency $(\mathrm{Hz})$ & $\gamma\left(\mathrm{mN} \mathrm{m}^{-1}\right)$ & $\varepsilon\left(\mathrm{mN} \mathrm{m}^{-1}\right)$ & Method/Remarks & Reference \\
\hline PLSAP & 0.841 & 60.2 & 14.5 & Drop Tensiometer (surface age $=500 \mathrm{~min}$ ) & this work \\
\hline Ovoalbumin $(0.01 \%)$ & 0.1 & 56.5 & 35 & Drop Tensiometer(surface age $=85 \mathrm{~min})$ & 15 \\
\hline Ovoalbumin $(0.001 \%)$ & 0.1 & 68.8 & 17.2 & Drop Tensiometer(surface age $=75 \mathrm{~min})$ & 15 \\
\hline BSA $(0.01 \%)$ & 0.1 & 56.2 & 17.3 & Drop Tensiometer(surface age $=75 \mathrm{~min})$ & 38 \\
\hline Lysozyme $(0.01 \%)$ & 300 & $\sim 55$ & $\sim 42$ & Capillary wave probe & 39 \\
\hline$\beta$-lactoglobulin $\left(10^{-7} \mathrm{~mol} \mathrm{~L}^{-1}\right)$ & $\sim 0.018$ & $\sim 55$ & $\sim 10$ & Drop Tensiometer(surface age $=60 \mathrm{~min}$ ) & 31 \\
\hline
\end{tabular}

covalently bound to the polypeptidic moiety of the protein gives the GPI-anchored alkaline phosphatase extremely peculiar surface properties, with the GPI-anchor driving the processes of adsorption, orientation, ${ }^{10,25,46-48}$ and packing ${ }^{9}$ and, as stated by the present work, also influencing the surface elasticity properties. To the best of our knowledge, this is the first report concerning the elasticity properties of a GPI-anchored protein.

\section{Conclusions}

We have demonstrated that the enzyme form lacking a hydrophobic anchor (PLSAP) exhibits surface activity due to the adsorption of the polypeptide moiety of the enzyme at the air/water interface. As expected, the hydrophobic anchor-containing form (DSAP) has a higher surface activity due to the presence of the hydrophobic anchor. The elasticity of alkaline phosphatase at a certain frequency and amplitude depends on the following factors: presence of the GPI anchor, concentration, surface pressure, solubility induced by non-ionic surfactant and surface packing. The anchor-containing form (DSAP) has an elasticity modulus higher than the lacking-anchor form (PLSAP) at the same surface pressure. In the studied frequency, the elasticity modulus is associated to the CAC of the surfactant/enzyme system. Since PLSAP has a high mobility due to its hydrophilic character and low concentration, it displays elasticity values that decrease with concentration. This work will certainly help the understanding of the rheological behavior of enzyme/ phospholipid interfaces and also state the differences in the dilatational elasticity of the liquid interface in the presence of enzymes.

\section{Acknowledgments}

The authors thank FAPESP for financial support and are grateful to Dr. T.Holz and Dr. C. M.C. P. Manso for the careful reading of the manuscript, to Dr. I. Borin for adaptation of Figure 1. L. Caseli thanks FAPESP for his Ph.D. fellowship. M.E.D.Zaniquelli and F.A.Leone are CNPq research fellows.

\section{References}

1. Lucassen-Reynders, E.H.; Wasan D.T.; Food Structure 1993, 12,1 .

2. Stubenrauch, C.; Miller, R.; J. Phys. Chem. B 2004, 108, 6412 .

3. Lunkenheimer, K.; Winsel, K.; Fruhner, H.; Fang, J.; Wantke, K.D.; Siegler, K.; Colloids Surfaces A 1996, 114, 199.

4. Ivanova, T.; Minkov I.; Panaiotov, I.; Saulnier, P.; Proust, J.E.; Colloid Polymer Sci. 2004, 282, 1258.

5. Caseli, L.; Masui, D.C.; Furriel, R.P.M.; Leone, F.A.; Zaniquelli, M.E.D.; Oliveira, R.G.; Maggio, B.; Abstract of the XVIII Congresso Soc. Bras. Biofísica, Rio de Janeiro, Brazil, 2003.

6. Ciancaglini, P.; Pizauro, J.M.; Rezende, A.A.; Rezende, L.A.; Leone, F.A.; Int. J. Biochem. 1990, 22, 385.

7. Pizauro, J.M.; Ciancaglini, P.; Leone, F.A.; Mol. Cell Biochem. 1995, 152, 121.

8. Ferguson, M. A. J.; Biochem. Soc. Trans. 1992, 20, 243.

9. Leone, F. A.; Pizauro, J. M.; Ciancaglini, P.; Trends Comp. Biochem. Physiol. 1997, 3, 57.

10. Caseli, L.; Furriel, R.P.M.; Andrade, J.F.; Zaniquelli, M.E.D.; J. Colloid Interface Sci. 2004, 275, 123.

11. Lucassen, J.; van den Tempel, M.; Chem. Eng. Sci. 1972, 27, 1283.

12. Benjamins, J.; de Feijter, J. A.; Evans, M. T. A.; Graham, D. E.; Phillips, M. C.; Faraday Discussions 1975, 59, 218.

13. Lunkenheimer, K.; Kretzschmar, G.; Z. Phys. Chem. 1975, 256, 593.

14. Ting, L.; Wasan, D. T.; Miyano, K.; J. Colloid Interface Sci. 1985, 107, 345 .

15. Tian, Y.; Holt, R. G.; Apfel, R. E.; J. Colloid Interface Sci. 1997, 187, 1.

16. Benjamins, J.; Cagna, A.; Lucassen-Reynders, E. H.; Colloids Surfaces A 1996, 114, 245

17. Warszynski, P.; Wantke, K. D.; Fruhner, H.; Colloids Surfaces A 2001, 189, 29.

18. Rotenberg, Y.; Boruvka, L.; Neumann, A.W.; J. Colloid Interface Sci. 1983, 83, 169.

19. Zholkovskij, E. K.; Kovalchuk, V. I.; Fainerman, V. B.; Loglio, G.; Kragel, J.; Miller, R.; Zholob, S. A.; Dukhin, S. S.; J. Colloid Interface Sci. 2000, 224, 47. 
20. Cheng, P.; Li, D.; Boruvka, L.; Rotenberg, Y.; Neumann, A. W.; Colloids Surfaces 1990, 43, 151.

21. Curti, C.; Pizauro, J. M.; Rossinholi, G.; Vugman, I.; Mello de Oliveira, J. A.; Leone, F. A.; Cell. Mol. Biol. 1986, 32, 55.

22. Anand, K.; Damodaran, S.; J. Colloid Interface Sci. 1995, 176, 63.

23. Miller, R.; Aksenenko, E. V.; Fainerman, V. B.; Pison, U.; Colloids Surfaces A 2001, 183-185, 381.

24. Freer, E. M.; Yim, K. S.; Fuller, G. G.; Radke, C. J.; J. Phys. Chem. B 2004, 108, 3835.

25. Caseli, L.; Zaniquelli M. E. D.; Furriel, R. P. M.; Leone, F. A.; Colloids Surfaces B 2002, 25, 119.

26. Caseli, L.; Zaniquelli, M. E. D.; Furriel, R. P. M.; Leone, F. A.; Colloids Surfaces B 2003, 30, 273.

27. Beverung, C. J.; Radke, C. J.; Blanch, H. W.; Biophys. Chem. 1999, 59, 80.

28. Anderson, R. E.; Pande, V. S.; Radke, C. J.; J. Chem. Phys. 2000, 112, 9167.

29. Graham, D. E.; Philips, M. C.; J. Colloid Interface. Sci. 1979, $70,403$.

30. Benjamins, J.; Vader, F. V.; Colloids Surfaces 1992, 65, 161.

31. Rao, C. S.; Damodaran, S.; Langmuir 2000, 16, 9468.

32. Ravera, F.; Liggieri, L.; Miller, R.; Colloids Surfaces A 2000, $175,51$.

33. Wüstneck, R.; Moser, B.; Muschiolik, G.; Colloids Surfaces B 1999, 15, 263.

34. Krause, J. P.; Wüstneck, R.; Seifert, A.; Schwenke, K. D.; Colloid Surfaces B 1998, 10, 119.

35. Liggieri, L.; Attolini, V.; Ferrari, M.; Ravera, F.; J. Colloid Interface Sci. 2002, 255, 225.
36. Stubenrauch, C.; Miller, R.; J. Phys. Chem. B 2004, 108, 6412.

37. Miller, R.; Fainerman, V. B.; Makievski, A.V.; Krägel, J.; Grigoriev, D. O.; Kazakov, V. N.; Sinyachenko, O. V.; Adv. Colloid Interface Sci. 2000, 86, 39.

38. Benjamins, J.; Cagna, A.; Lucassen-Reynders, E.H.; Colloids Surfaces A 1998, 143, 245.

39. Jiang, Q.; Chiew, Y. C.; Colloids Surfaces B 2001, 20, 303.

40. Miller, R.; Trends Polymer Sci. 1991, 2, 47.

41. Ward, A. J. I.; Regan, R. H.; J. Colloid Interface Sci. 1980, 78, 389.

42. Graham, D. E.; Philips, M. C.; J. Colloid Interface Sci. 1980, $76,227$.

43. Le Du, M.H.; Stigbrand, T.; Taussig, M. J.; Menez, A.; Stura, E. A.; J. Biol. Chem. 2001, 276, 9158.

44. Murray, B. S.; Ventura, A.; Lallemant, C.; Colloids Surfaces A 1998, 143, 211.

45. Fainerman, V. B.; Miller, R. In Studies of Interface Science: Proteins at Liquid Interfaces; Möbius, D.; Miller, R., eds., Elsevier: Amsterdam, Netherlands, 1998, vol. 7.

46. Ronzon, F.; Desbat, B.; Chauvet, J.P.; Roux, B.; Biochim. Biophys. Acta 2002, 1560, 1.

47. Ronzon, F.; Desbat, B.; Chauvet, J. P.; Roux, B.; Colloids Surface B 2002, 23, 365.

48. Ronzon, F.; Desbat, B.; Buffeteau, T.; Mingotaud, C.; Chauvet, J. P.; Roux, B.; J. Phys. Chem.B 2002, 106, 3307.

Received: February 14, 2005 Published on the web: July 27, 2005

FAPESP helped in meeting the publication costs of this article. 